\title{
Toscana, West Nile, Usutu and tick-borne encephalitis viruses: external quality assessment for molecular detection of emerging neurotropic viruses in Europe, 2017
}

Chantal Reusken ${ }^{1,2}$, Cecile Baronti ${ }^{3}$, Ramona Mögling $^{1}$, Anna Papa ${ }^{4}$, Katrin Leitmeyer ${ }^{5}$, Remi N Charrel ${ }^{3}$

1. Department of Viroscience, Erasmus University Medical Centre, Rotterdam, the Netherlands

2. Centre for Infectious Disease Control, National Institute for Public Health and the Environment (RIVM), Bilthoven, the Netherlands

3. Unite des Virus Emergents (UVE: Aix Marseille Univ, IRD 190, INSERM 1207, IHU Mediterranee Infection), Marseille, France

4. Department of Microbiology, Medical School, Aristotle University of Thessaloniki, Thessaloniki, Greece

5. European Centre for Disease Prevention and Control (ECDC), Solna, Sweden

Correspondence: Remi N Charrel (remi.charrel@univ-amu.fr)

Citation style for this article:

Reusken Chantal, Baronti Cecile, Mögling Ramona, Papa Anna, Leitmeyer Katrin, Charrel Remi N. Toscana, West Nile, Usutu and tick-borne encephalitis viruses: external quality assessment for molecular detection of emerging neurotropic viruses in Europe, 2017. Euro Surveill. 2019;24(50): pii=1900051. https://doi. org/10.2807/1560-7917.ES.2019.24.50.1900051

Background: Neurotropic arboviruses are increasingly recognised as causative agents of neurological disease in Europe but underdiagnosis is still suspected. Capability for accurate diagnosis is a prerequisite for adequate clinical and public health response. Aim: To improve diagnostic capability in EVD-LabNet laboratories, we organised an external quality assessment (EQA) focusing on molecular detection of Toscana (TOSV), Usutu (USUV), West Nile (WNV) and tick-borne encephalitis viruses (TBEV). Methods: Sixty-nine laboratories were invited. The EQA panel included two WNV RNA-positive samples (lineages 1 and 2), two TOSV RNA-positive samples (lineages $A$ and $B$ ), one TBEV RNA-positive sample (Western subtype), one USUV RNA-positive sample and four negative samples. The EQA focused on overall capability rather than sensitivity of the used techniques. Only detection of one, clinically relevant, concentration per virus species and lineage was assessed. Results: The final EQA analysis included 51 laboratories from 35 countries; 44 of these laboratories were from 28 of 31 countries in the European Union/European Economic Area (EU/EEA). USUV diagnostic capability was lowest (28 laboratories in 18 countries), WNV detection capacity was highest (48 laboratories in 32 countries). Twenty-five laboratories were able to test the whole EQA panel, of which only 11 provided completely correct results. The highest scores were observed for WNV and TOSV (92\%), followed by TBEV ( $86 \%)$ and USUV $(75 \%)$. Conclusion: We observed wide variety in extraction methods and RT-PCR tests, showing a profound absence of standardisation across European laboratories. Overall, the results were not satisfactory; capacity and capability need to be improved in 40 laboratories.

\section{Background}

The aetiology of neuro-invasive viral infections remains undetermined in more than $50 \%$ of cases [1]. Several viruses can cause infections of the central nervous system (CNS) while, regardless of the causative aetiology, clinical manifestations are often similar, making a confirmed diagnosis dependant on laboratory testing [2]. Neurotropic arboviruses are increasingly recognised as causative agents of neurological disease in Europe but underdiagnosis is still suspected [3]. Confirmed involvement of arboviruses is important for risk communication and risk management strategies, the latter including activities like local vector control, blood safety measures and vaccination campaigns. Four neurotropic arboviruses are emerging and have become endemic in large parts of Europe: Toscana virus (TOSV), Usutu virus (USUV), West Nile virus (WNV) and tick-borne encephalitis virus (TBEV).

The TOSV (genus Phlebovirus, family Phenuiviridae) is transmitted by sandflies of the genus Phlebotomus and circulates in Mediterranean countries where it can cause febrile illness and neuroinvasive infections. At least 250 million people are exposed in Europe and neighbouring countries around the Mediterranean basin that are frequently visited by travellers for occupational or leisure purposes [4-7]. In France, Spain and Italy, TOSV is among the three most common agents causing aseptic meningitis and encephalitis, together with enteroviruses and herpesviruses (herpes simplex 
TABLE 1

Nucleic acid extraction methods used in the external quality assessment for molecular detection of emerging neurotropic viruses, Europe ( $\mathrm{n}=51$ laboratories)

\begin{tabular}{|l|c|}
\hline Extraction method & Number of laboratories \\
\hline QIAamp Viral RNA Mini Kit (Qiagen, Hilden) & 21 \\
\hline NucliSENSE EasyMag (BioMérieux, Marcy-L'étoile) & 4 \\
\hline EZ1 Virus Mini Kit (Qiagen, Hilden) & 3 \\
\hline MagNA Pure 96 DNA and Viral NA kit (Roche, Meylan) & 3 \\
\hline RNeasy Mini kit (Qiagen, Hilden) & 2 \\
\hline QIAamp MinElute Virus Spin Kit (Qiagen, Hilden) & 2 \\
\hline MagNa Pure LC total NA kit (Roche, Meylan) & 2 \\
\hline MagNa Pure Compact NA isolation kit (Roche, Meylan) & 2 \\
\hline iPrep PureLink Virus Kit (Thermo Fisher, Bourgoin-Jallieu) & 2 \\
\hline QIAamp DSP Virus (Qiagen, Hilden) & 2 \\
\hline Maxwell RSC Viral Total NA Purification Kit (Promega, Charbonnières-les-Bains) & 1 \\
\hline QIAxtractor VX (Qiagen, Hilden) & \\
\hline QIAamp RNA Blood Mini Kit (Qiagen, Hilden) & \\
\hline MagCore Viral NA extraction kit (RBCBioscience, New Taipei City) & \\
\hline TriPure isolation reagent (Sigma-Aldrich, Saint-Louis) & 1 \\
\hline High Pure Viral RNA kit (Roche, Meylan) & \\
\hline NucleoSpin RNA Virus (Macherey-Nagel, Düren) & 1 \\
\hline MagDea NA extraction kit for magLead (PSS-Ltd, Tokyo) & \\
\hline RIBO-prep NA extraction kit (AmpliSense, Voisins-Le-Bretonneux) & \\
\hline
\end{tabular}

and varicella-zoster viruses) [8]. Viraemia is shortlived (typically 5 days, range: $2-7$ ) and diagnosis is done either by detecting viral RNA in cerebrospinal fluid (CSF) or serum at the acute stage of infection or by detecting IgM in an early serum sample [8]. The currently known circulation of three genetic lineages may be indicative of a wide genetic diversity of this viral species and thus molecular assays are needed to detect genetic variants [8].

WNV (genus Flavivirus, family Flaviviridae) is transmitted by Culex spp. mosquitoes. WNV can cause febrile illness with or without neurological manifestations. During the last decade, WNV activity in Europe has shown a profile similar to that observed in North America, with substantial activity reported every year and with recurring major outbreaks $[9,10]$. Major recent activity in the eastern Mediterranean region is also a matter of concern for Europe [11].

Lineages 1 and 2 have been identified in human WNV cases in Europe [12]. Severe cases are more frequent in elderly and immunocompromised patients. In the acute stage of disease, WNV RNA can be detected in CSF. WNV viraemia is typically short-lived, but viral RNA can be detected for longer periods in some specimens such as urine and whole blood, and also in fatal cases or immunocompromised patients. The high degree of cross-reactivity with other flaviviruses in serology is problematic. Although a combination of serology and $P C R$ is desirable, the detection of WNV RNA alone is an important means of undisputable confirmation of acute infection [13].

USUV (genus Flavivirus, family Flaviviridae) was first isolated in Africa in 1959 [13]. It is a Culex-transmitted flavivirus closely related to WNV [13]. The earliest human cases (presenting as neuro-invasive disease) were recorded in 2009 in Italy in two immunocompromised patients having received blood products [13]. Since then evidence of zoonotic transmission accompanied by neurological disease of USUV is accumulating while population studies show the occurrence of asymptomatic infections [13]. Nothing is known about the length of USUV viraemia and the kinetics of antibody production in humans [13]. Based on its close relatedness to WNV, viraemia is expected to be short and low level [13]. At the acute stage of neuroinvasive infection the virus is expected to be detectable by RT-PCR in CSF. A high degree of cross-reactivity with other flaviviruses is seen in serology. For this reason, molecular detection is the preferred method for confirmatory laboratory diagnosis.

TBEV (genus Flavivirus, family Flaviviridae) is a tickborne flavivirus; the incidence of TBEV infection in humans and its geographical distribution have increased in Europe [14]. Three subtypes are recognised, of which the Western subtype is endemic in northern, central and eastern Europe. The clinical spectrum of the disease ranges from mild meningitis to severe meningoencephalitis. The course of TBE is often biphasic. The first acute phase typically has 


\section{FIGURE 1}

Number of laboratories per country that provided results for Toscana virus, external quality assessment for molecular detection of emerging neurotropic viruses, Europe $(n=32$ laboratories)

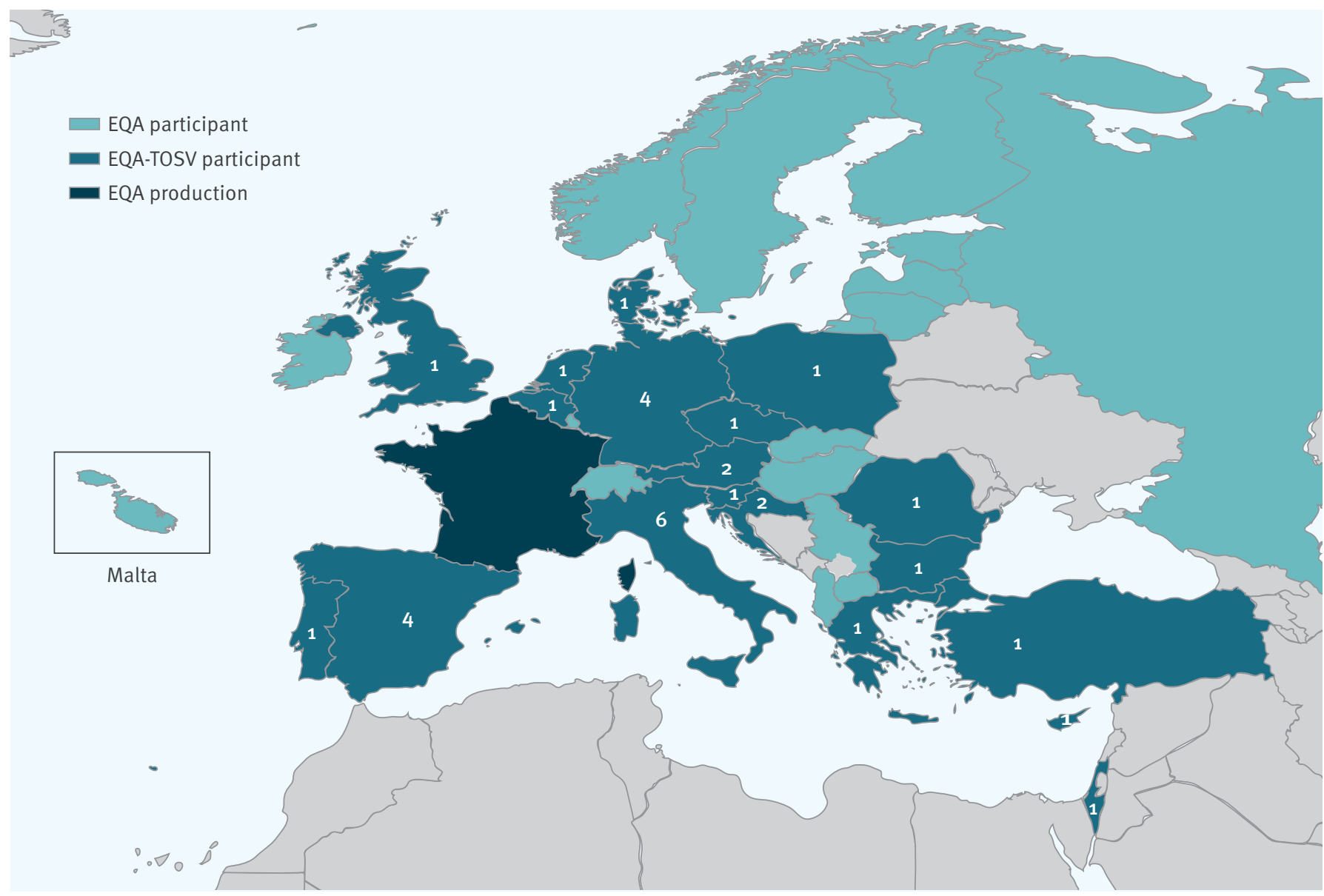

EQA: external quality assessment; TOSV: Toscana virus.

Blue: countries participating with TOSV RNA testing; dark blue: France (the Unite des Virus Emergents (National Reference Centre for arboviruses) at Aix Marseille University prepared and anonymised the panel); light blue: countries that submitted results for viruses other than TOSV.

non-specific symptoms. It is followed by an asymptomatic interval that precedes the second phase characterised by neuroinvasive disease. Therefore, the window of molecular detection in serum and CSF is often missed as diagnostics are typically requested during the second phase of illness. Once neurological symptoms are manifest, TBEV RNA is rarely detected in blood and CSF. However, in endemic regions, unexplained febrile illness alone can justify molecular testing. As TBEV cases often do not present with typical symptoms, diagnosis often relies on laboratory documentation. As for WNV, viraemia is typically short-lived and low while serology is hampered by extensive crossreactivity among flaviviruses [15].

To support molecular diagnostic capacity and capability building for these emerging neurotropic viruses in the European Union(EU)/ European Economic Area (EEA) and EU pre-accession countries, an external quality assessment (EQA) was organised for members of the expert laboratory network EVD-LabNet (https://www. evd-labnet.eu/) funded by the European Centre for Disease Prevention and Control. Here, we present this assessment and the inventory of methods for RT-PCR detection of these viruses that are used in European and national reference laboratories.

\section{Methods}

\section{EQA scheme organisation}

All members of EVD-LabNet (69 laboratories at 1 November 2017) were invited by email to participate through online registration. Fifty-four laboratories from 35 countries registered online.

\section{Panel composition}

The EQA panel consisted of 10 samples with six samples positive for one of four different viral species (plasma samples spiked with viruses), and four negative control samples. The panel included two 
TABLE 2

RT-PCR methods used for Toscana virus RNA detection, external quality assessment for molecular detection of emerging neurotropic viruses, Europe ( $\mathrm{n}=32$ laboratories).

\begin{tabular}{|c|c|c|c|}
\hline Target & Method & Number of laboratories & False-negative ${ }^{a}$ \\
\hline \multicolumn{4}{|l|}{ Toscana virus-specific } \\
\hline TOSV N & Perez-Ruiz et al., $2007[29]^{\mathrm{b}}$ & 13 & 1 (lineage B) \\
\hline TOSV N & Weidmann et al., 2008 [30] $^{\mathrm{b}}$ & 5 & None \\
\hline TOSV N & Brisbarre et al., $2015[31]^{\mathrm{b}}$ & 2 & None \\
\hline TOSV L & Sanchez-Seco et al., $2003[43]^{\mathrm{c}}$ & 1 & 1 (lineage B) \\
\hline TOSV various & Own design ${ }^{d}$ & 5 & 1 (lineage B) \\
\hline TOSV N & Progenie (commercial)b & 1 & None \\
\hline \multicolumn{4}{|l|}{ Pan-phlebovirus } \\
\hline Pan-phlebo L/N & Sanchez-Seco et al., 2003 [43] & 7 & $\begin{array}{l}1 \text { (lineage A), } \\
2 \text { (lineage B) }\end{array}$ \\
\hline Pan-phlebo N & Lambert and Lanciotti, 2009 [44] & 1 & 1 (lineage B) \\
\hline Pan-phlebo unknown & Own design ${ }^{d}$ & 1 & None \\
\hline
\end{tabular}

TOSV: Toscana virus.

a The missed TOSV lineage is indicated between brackets.

b Included in statistical analysis as classified as virus-specific real-time RT-PCR.

c Included in statistical analysis as classified as conventional RT-PCR.

${ }^{d}$ Excluded from statistical analysis as no distinction could be made whether it is real-time RT-PCR or conventional RT-PCR.

e Not all participants indicated which of two pan-Phlebo RT-PCRs in the reference was used.

WNV RNA-positive samples (WNV lineage 1, strain UVE/WNV/2001/FR/DON2001 (ref\#001V-02215), $7.2 \times 10^{4}$ RNA copies/0.4 mL [16] and WNV lineage 2, strain B956 source BNI, Hamburg, $4.96 \times 10^{5}$ RNA copies/0.4 mL), two TOSV RNA-positive samples (TOSV lineage A, strain UVE/TOSV/2010/TN/ T152 (ref\#001V-02119), $1.57 \times 10^{5}$ RNA copies/o.4 mL [17] and TOSV lineage $B$, strain UVE/TOSV/2010/FR/4319 (ref\#001V-02442), $1.24 \times 10^{5}$ RNA copies/o.4 mL [18]), one TBEV RNA-positive sample (Western subtype, strain UVE/TBEV/1953/CZ/Hypr (ref\#o01V-EVA134), $5.06 \times 10^{4}$ RNA copies/0.4mL [19]), one USUV RNApositive sample (USUV, strain Turdus merula NL2016 (ref\#011V-02153), $6.34 \times 10^{3}$ RNA copies/o.4 mL) [20] and four viral RNA-negative plasma samples. Strains referenced in the European Virus Archive (EVA) can be accessed at https://www.european-virus-archive.com. Each sample of the panel was prepared from a batch that consisted of qualified non-therapeutic human plasma obtained from the French blood bank, spiked with virus culture supernatant and heat-inactivated at $60^{\circ} \mathrm{C}$ for 1 hour. A total of $700.4-\mathrm{mL}$ aliquots were prepared and freeze-dried into glass vials. Proper inactivation was confirmed by the absence of cytopathic effect in Vero cells and by undetectable increase of the viral RNA titre in the supernatant 5 days after inoculation. The viral loads per reconstituted sample were quantified with reference to in-house TOSV-, WNV-, TBEVand USUV-specific synthetic RNA controls; a fragment (ca $500 \mathrm{bp}$ ) tagged at the 5'end with the T7 promoter sequence (5'TAATACGACT CACTATAGGG3') and containing the virus-specific TaqMan-targeted sequence was amplified by RT-PCR using the Access RT-PCR kit (Promega, Charbonnières-les-Bains). The resulting PCR products were purified and transcribed using the T7 Megashort script kit (Ambion, ThermoFisher Scientific, Bourgoin-Jallieu). The obtained RNA was purified with the MegaClear purification kit (Ambion, Bourgoin-Jallieu). RNA concentration was measured using a NanoDrop 1000 (Thermo Scientific, BourgoinJallieu) and translated into copy numbers. Real-time RT-PCR was performed using the Express One-Step Superscript qRT-PCR Kit, universal (Life technologies, Bourgoin-Jallieu) on a QuantStudio 12K Flex Real-Time PCR System. For each EQA sample, the number of copies contained in $0.4 \mathrm{~mL}$ of freeze-dried material in the glass vial was calculated by comparison with a dilution series of T7-generated RNA standard containing $10^{2}$ to $10^{8}$ RNA copies.

Result submission, evaluation and EQA scoring We provided the Laboratories with a link to an online form to submit their EQA results. Laboratories could indicate for which of the four target viruses they had tested the EQA panel and background information of the diagnostic tests that the laboratory assessed with the EQA. Data were collected and analysed in Microsoft Excel 2011. Fisher's exact test (www.socscistatistics. com/tests/fisher/Default2.aspx) was used to compare the rate of false-negative results obtained with virusspecific real-time assays and with other assays for TOSV, USUV, TBEV and WNV. Fisher's exact test was used because the significance of the deviation from a null hypothesis can be calculated exactly, rather than relying on an approximation that becomes exact in the 
TABLE 3

Summary of results of laboratories in the external quality assesment on molecular diagnostics of emerging neurotropic viruses, Europe $(\mathrm{n}=51)$

\begin{tabular}{|c|c|c|c|c|c|c|c|c|c|c|}
\hline Sample ID & $1^{\mathrm{a}}$ & 2 & 3 & 4 & 5 & 6 & 7 & 8 & 9 & 10 \\
\hline Virus & $\begin{array}{l}\text { TOSV } \\
\text { (lineage } \\
\text { A) }\end{array}$ & $\begin{array}{l}\text { TOSV } \\
\text { (lineage } \\
\text { B) }\end{array}$ & USUV & $\begin{array}{l}\text { WNV } \\
\text { (lineage } \\
1 \text { ) }\end{array}$ & $\begin{array}{l}\text { WNV } \\
\text { (lineage } \\
\text { 2) }\end{array}$ & TBEV & Negative & Negative & Negative & Negative \\
\hline Concentration & $\begin{array}{c}1.57 \mathrm{X} \\
10^{5} \mathrm{RNA} \\
\mathrm{cp} / 0.4 \mathrm{~mL}\end{array}$ & \begin{tabular}{|c|}
$1.24 \mathrm{X}$ \\
$10^{5} \mathrm{RNA}$ \\
$\mathrm{cp} / 0.4 \mathrm{~mL}$ \\
\end{tabular} & \begin{tabular}{|c|}
$6.34 \mathrm{x}$ \\
$10^{3} \mathrm{RNA}$ \\
$\mathrm{cp} / 0.4 \mathrm{~mL}$ \\
\end{tabular} & $\begin{array}{c}7.2 \mathrm{x} \\
10^{4} \mathrm{RNA} \\
\mathrm{cp} / 0.4 \mathrm{~mL}\end{array}$ & $\begin{array}{c}4.96 x \\
10^{5} \text { RNA } \\
\text { cp/o.4mL }\end{array}$ & $\begin{array}{c}5.06 x \\
10^{4} \text { RNA } \\
\text { cp/o.4mL }\end{array}$ & $\mathrm{n} / \mathrm{a}$ & $\mathrm{n} / \mathrm{a}$ & $\mathrm{n} / \mathrm{a}$ & $\mathrm{n} / \mathrm{a}$ \\
\hline $\begin{array}{l}\text { Total correct positive when } \\
\text { tested for the specific virus }\end{array}$ & $31 / 51$ & $28 / 51$ & $23 / 51$ & $42 / 51$ & $46 / 51$ & $37 / 51$ & $\mathrm{n} / \mathrm{a}$ & $\mathrm{n} / \mathrm{a}$ & $\mathrm{n} / \mathrm{a}$ & $\mathrm{n} / \mathrm{a}$ \\
\hline $\begin{array}{l}\text { Total correct positive when } \\
\text { not tested for the specific } \\
\text { virus }\end{array}$ & $17 / 51$ & $18 / 51$ & $19 / 51$ & $2 / 51$ & $2 / 51$ & $8 / 51$ & $\mathrm{n} / \mathrm{a}$ & $\mathrm{n} / \mathrm{a}$ & $\mathrm{n} / \mathrm{a}$ & $\mathrm{n} / \mathrm{a}$ \\
\hline Total correct & $48 / 51$ & $46 / 51$ & $42 / 51$ & $44 / 51$ & $48 / 51$ & $45 / 51$ & $47 / 51$ & $48 / 51$ & $49 / 51$ & $48 / 51$ \\
\hline $\begin{array}{l}\text { Total partially correct: } \\
\text { identification at the genus } \\
\text { level }\end{array}$ & $0 / 51$ & $0 / 51$ & $1 / 51$ & $2 / 51$ & $1 / 51$ & $2 / 51$ & $\mathrm{n} / \mathrm{a}$ & $\mathrm{n} / \mathrm{a}$ & $\mathrm{n} / \mathrm{a}$ & $\mathrm{n} / \mathrm{a}$ \\
\hline False & $4 / 51$ & $5 / 51$ & $5 / 51$ & $5 / 51$ & $2 / 51$ & $4 / 51$ & $3 / 51$ & $3 / 51$ & $1 / 51$ & $3 / 51$ \\
\hline Total sentivity & $31 / 32$ & $28 / 32$ & $21 / 28$ & $42 / 48$ & $46 / 48$ & $36 / 42$ & $\mathrm{n} / \mathrm{a}$ & $\mathrm{n} / \mathrm{a}$ & $\mathrm{n} / \mathrm{a}$ & $\mathrm{n} / \mathrm{a}$ \\
\hline
\end{tabular}

n/a: not applicable; TBEV: tick-borne encephalitis virus; TOSV: Toscana virus; USUV: Usutu virus; WNV: West Nile virus.

${ }^{a}$ Number $>100 \%$ as one laboratory submitted both a correct result (positive for TOSV) and one false result (positive for TBEV) for this sample.

limit as the sample size grows to infinity, as with the chi-squared test.

\section{Results}

\section{EQA participation}

The final EQA analysis included 51 laboratories form 35 countries: 44 laboratories from 28 EU/EEA countries, four laboratories from four EU pre-accession countries (Albania, North Macedonia, Serbia and Turkey) and three laboratories from three non-EU/EEA countries (Israel, Russia and Switzerland). From the EU/ $E E A$, there was no participation from laboratories in Iceland and France besides the reference laboratory in Marseille that produced the panel. Liechtenstein does not have a reference laboratory participating in EVDLabNet. From EU pre-accession countries, there was no participation by Bosnia and Herzegovina, Montenegro and Kosovo*, the two latter being not members of EVDLabNet at the time.

\section{Nucleic acid extraction methodology}

The different techniques used for extraction of nucleic acids are presented in the Table 1. Various Qiagen kits were used by 31 laboratories: 21 used the QIAamp Viral RNA Mini Kit (Qiagen, Hilden) and the remaining 10 laboratories used six different Qiagen kits. The extraction kits from Roche (Meylan) were the second most frequently used brand, with eight laboratories using four different types of Roche kits. Because of the high diversity, it was impossible to include the type of RNA purification in the analysis.

\section{Toscana virus}

Of the 51 laboratories, 32 laboratories in 19 countries (17 EU/EEA, one EU candidate, one other) tested the panel for the presence of TOSV RNA (Figure 1). Nineteen laboratories in 19 countries had no TOSV test available. Seven laboratories used a pan-phlebovirus RT-PCR only, 23 laboratories a TOSV-specific RT-PCR only and two laboratories used both type of tests in combination. Some laboratories used more than one TOSVspecific or pan-phlebovirus test (Table 2).

Excluding TOSV-specific assays for which no information was available $(n=10)$, TOSV-specific real-time tests $(n=42)$ provided false-negative results significantly less frequently than all other tests together (panphlebo, classic and nested RT-PCR; $n=20 ; p=0.011$ ). Thirty-one of the 32 laboratories detected TOSV RNA correctly in sample \#1 (lineage A) and 28 laboratories detected TOSV RNA correctly in sample \#2 (lineage B). The RT-PCR tests used by laboratories that missed the presence of TOSV in sample \#1 $(n=1)$ or in sample \#2 $(n=6)$ are presented in Table 2 . One laboratory falsely detected TBEV RNA besides TOSV RNA in sample \#1 (Table 3).

\section{West Nile virus}

Forty-eight laboratories in 32 countries (26 EU/EEA, four EU candidates and two other) tested the panel for WNV RNA (Figure 2). One laboratory used a pan-flavi RT-PCR test while 28 laboratories used a WNV-specific RT-PCR. Eighteen laboratories used both a pan-flavi and WNV-specific RT-PCR, but the questionnaire did not allow linking the result with either assay. One laboratory did not report what type of test was used. Some laboratories used more than one RT-PCR test (Table 4). The diversity of WNV-specific tests used was high with a total of 25 different tests. Excluding WNVspecific assays for which no information was available $(n=4)$, there was no statistically significant difference 


\section{FIGURE 2}

Number of laboratories per country that provided results for West Nile virus, external quality assessment for molecular detection of emerging neurotropic viruses, Europe $(\mathrm{n}=48$ laboratories)

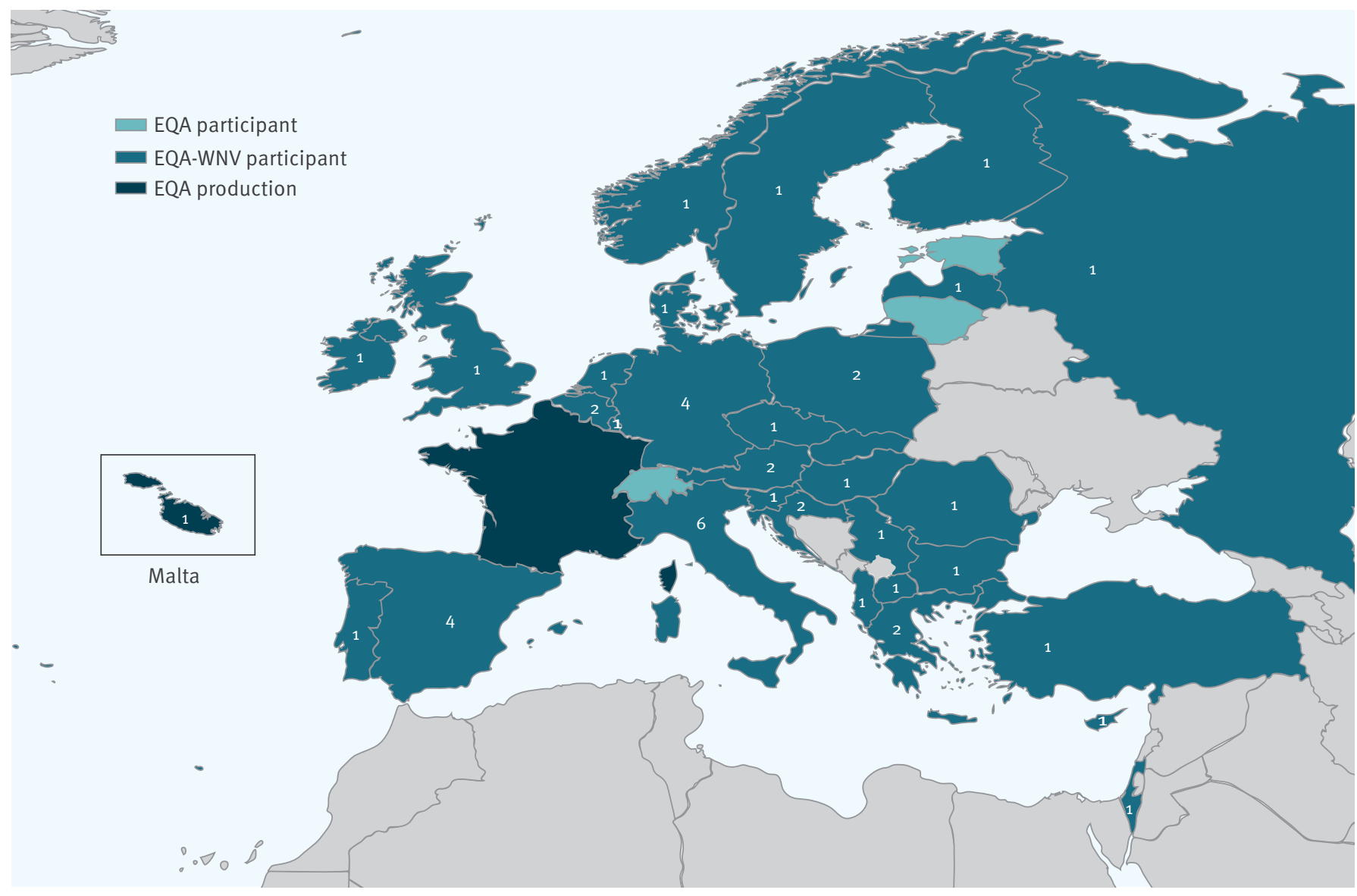

EQA: external quality assessment; WNV: West Nile virus.

Blue: countries participating with WNV RNA testing; dark blue: France (the Unite des Virus Emergents (National Reference Centre for arboviruses) at Aix Marseille University prepared and anonymised the panel); light blue: countries that submitted results for viruses other than WNV.

between results provided by WNV-specific real-time tests $(n=29)$ and all other tests together (real-time pan-flavi, classic and nested RT-PCR; $n=22 ; p=0.38$ ). Forty-two of 48 laboratories that tested the panel for the presence of WNV RNA detected WNV RNA correctly in sample \#4 (lineage 1), while one laboratory indicated to have detected flavivirus RNA. Five laboratories falsely scored sample \#4 as negative. WNV RNA was correctly identified in sample \# 5 (lineage 2) by 46 of 48 laboratories. Of the two laboratories providing a falsenegative result for sample $\#_{5}$, one laboratory reported the presence of TBEV RNA in sample \#5; the other reported the presence of flavivirus RNA, although it did not claim to test for WNV (Table 3 ).

\section{Usutu virus}

Twenty-eight laboratories in 18 countries (16 EU/EEA, two other) tested the panel for USUV (Figure 3). Six laboratories used a pan-flavivirus RT-PCR test only, 15 used an USUV-specific RT-PCR only and seven used both a pan-flavivirus and USUV-specific RT-PCR, but it was impossible to trace which one was used to provide the submitted results. Some laboratories used more than one USUV-specific or pan-flavivirus RT-PCR test. There was a lot of variation in USUV-specific RT-PCRS used, with 17 different test systems (Tables 3 and 5).

Excluding USUV-specific assays for which no information was available $(n=4)$, USUV-specific real-time tests $(n=20)$ provided false negative results significantly less frequently than all other tests together (real-time pan-flavi, classic and nested RT-PCR; $n=15 ; p=0019$ ). Seven of the 28 laboratories that tested the panel for USUV missed the positive sample \#6. The RT-PCR tests used by these laboratories are indicated in Table 5 .

\section{Tick-borne encephalitis virus}

Forty-two laboratories in 28 countries (25 EU/EEA, three other) tested the panel for TBEV RNA (Figure 4): seven used a pan-flavi RT-PCR test only, 24 used a TBEV-specific RT-PCR only and 11 used both a pan-flavi and TBEV-specific RT-PCR, however, the questionnaire 
TABLE 4

RT-PCR methods used for West Nile virus RNA detection, external quality assessment for molecular detection of emerging neurotropic viruses, Europe ( $\mathrm{n}=48$ laboratories)

\begin{tabular}{|c|c|c|c|}
\hline Target & Method & Number of laboratories & False-negative \\
\hline \multicolumn{4}{|c|}{ West Nile virus-specific } \\
\hline WNV $5^{6}-\mathrm{UTR} / \mathrm{C}$ & Linke et al., $2007[45]^{\mathrm{b}}$ & 11 & 1 (lineage 2) \\
\hline WNV $3^{6}$-UTR & Tang et al., $2006[47]^{\mathrm{b}}$ & 1 & None \\
\hline WNV 3'UTR & Lanciotti et al., $2000[48]^{\mathrm{b}}$ & 1 & None \\
\hline WNV E/NS1 & Shi et al., $2001[49]^{b}$ & 1 & None \\
\hline WNV NS3 & Chaskopoulou et al., 2011 [50] & 1 & None \\
\hline WNV various & Own design & 3 & 1 (lineage 1$)$ \\
\hline WNV unknown & Altona RealStar (commercial) & 5 & 1 (lineage 2) \\
\hline WNV unknown & 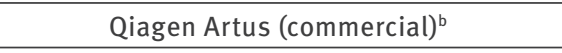 & 3 & 1 (lineage 1$)$ \\
\hline WNV unknown & Fast Track Tropical fever Core (commercial) ${ }^{b}$ & 3 & 1 (lineage 1$)$ \\
\hline WNV unknown & Sacace (commercial) ${ }^{b}$ & 1 & None \\
\hline \multicolumn{4}{|l|}{ Pan-flavivirus } \\
\hline Pan-flavi NS 5 & Scaramozzino et al., 2001 [51] & 7 & None \\
\hline Pan-flavi NS5 & Sanchez-Seco et al., 2005 [52] & 3 & None \\
\hline Pan-flavi NS5 & Moureau et al., 2007 [53] & 2 & 1 (lineage 1$)$ \\
\hline Pan-flavi NS5 & Patel et al., 2013 [54] & 2 & None \\
\hline Pan-flavi NS5 & Briese et al., 1999 [55] & 1 & None \\
\hline Pan-flavi NS5 & Vina-Rodriguez et al., 2017 [56] & 1 & None \\
\hline Pan-flavi NS 5 & Vazques et al., 2012 [57] & 1 & None \\
\hline Pan-flavi unknown & Own design & 2 & None \\
\hline Pan-flavi unknown & Genekam (commercial) & 1 & None \\
\hline Pan-flavi unknown & TibMolBiol (commercial) & 1 & None \\
\hline \multicolumn{2}{|c|}{ Information not provided ${ }^{c}$} & 1 & 1 (lineage 1$)$ \\
\hline
\end{tabular}

WNV: West Nile virus.

a WNV lineage missed indicated between brackets.

b Included in statistical analysis as classified as virus-specific real-time RT-PCR.

c Excluded from statistical analysis since cannot be classified as real-time RT-PCR or conventional RT-PCR.

did not permit to trace submitted results to one or the other assay. Moreover, some laboratories used more than one pan-flavivirus test. Table 6 gives an overview of the different RT-PCRs tests that were used on the EQA panel to detect TBEV RNA.

Excluding TBEV-specific assays for which no information was available $(n=4)$, there was no statistically significant difference between results provided by TBEV-specific real-time tests $(n=29)$ and all other tests together (real-time pan-flavi, classic and nested RT-PCR $n=25 ; p=1)$.

Thirty-six of 42 laboratories that tested the panel for the presence of TBEV RNA detected TBEV RNA correctly in sample \#3. Four laboratories falsely scored sample \#3 as negative including those using two commercial tests. One laboratory falsely indicated the presence of WNV RNA. One laboratory scored sample \#3 as panflavi-positive only (Table 3).

\section{Contamination}

Contamination issues were noticed in six of the 51 participating laboratories. Contamination issues involved detection of flavivirus, Zika virus, WNV or TBEV RNA in the negative control samples or in samples containing other specific viruses.

\section{Discussion}

Fifty-one laboratories from 35 countries (28 EU/EEA, four EU pre-accession, three non-EU/EEA) participated in this EQA on molecular detection of emerging neurotropic viruses. Twenty-five laboratories in 16 countries (15 EU/EEA, one non-EU/EEA) reported capacity for testing of all four EQA target viruses. However, only 11 of the 25 scored the panel $100 \%$ correct. These 11 laboratories represented 10 EU/EEA countries and one non-EU/EEA country. Overall, the results of the EQA are not satisfactory. The capacity and capability for molecular detection needs to be improved in the vast majority of the participating laboratories because these four viruses demonstrate a growing burden on 


\section{FIGURE 3}

Number of laboratories per country that provided results for Usutu virus, external quality assessment for molecular detection of emerging neurotropic viruses, Europe ( $\mathrm{n}=28$ laboratories)

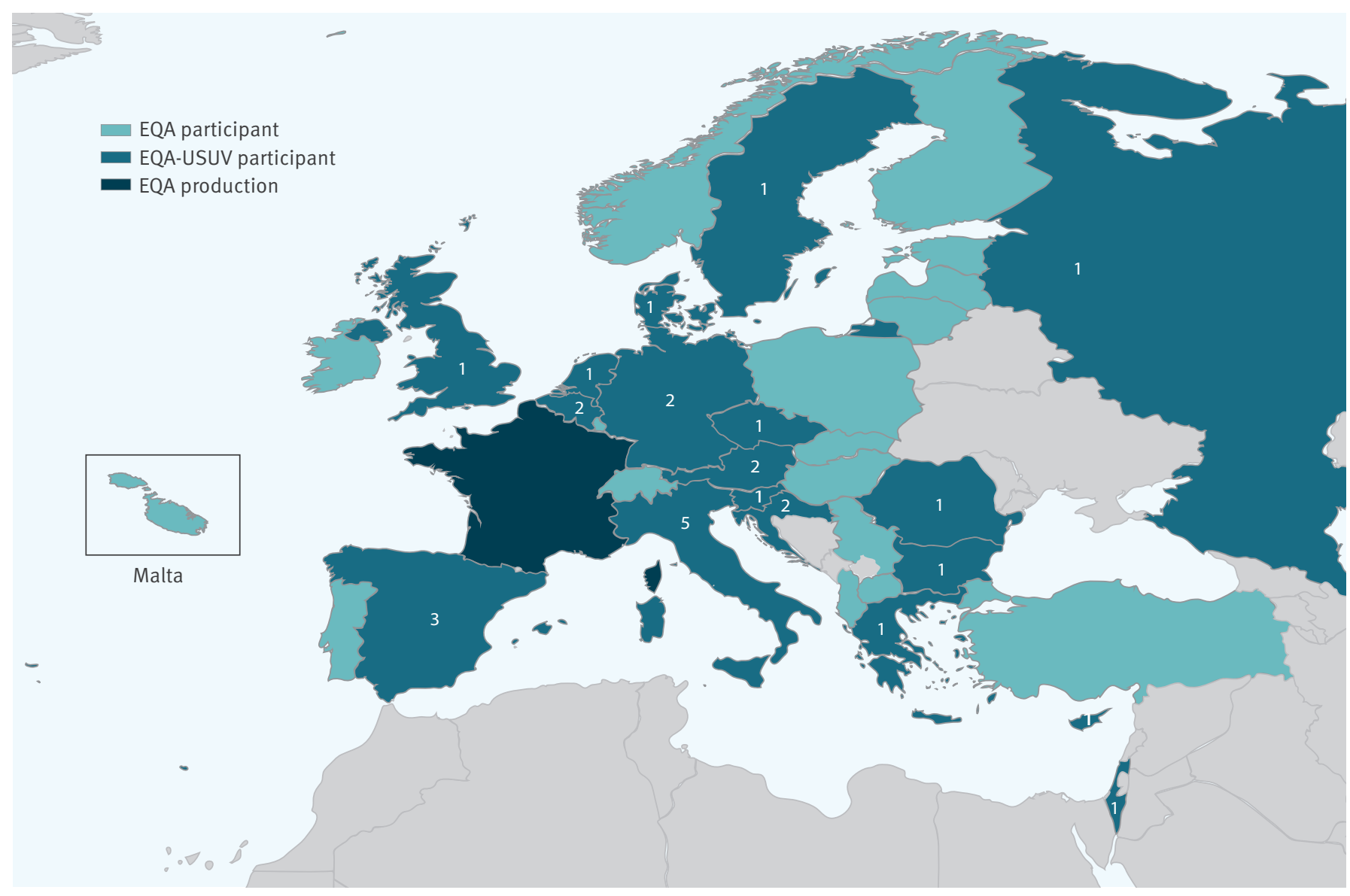

EQA: external quality assessment; USUV: Usutu virus.

Blue: countries participating with USUV RNA testing; dark blue: France (the Unite des Virus Emergents (National Reference Centre for arboviruses) at Aix Marseille University prepared and anonymised the panel); light blue: countries that submitted results for viruses other than USUV.

public health, have sympatric circulation (at least two of them) in several European countries and are indistinguishable clinically. It is important to underline that most of the participating laboratories were not first-line routine laboratories but national reference laboratories [3]. The fact that samples were missed by laboratories is of concern as the samples had RNA loads within the average of clinical relevance and were not intended to be at the detection limit to evaluate sensitivity. Another worrisome observation is the fact that six of 51 participating laboratories scored one or more of the viral RNA-negative samples positive, which is indicative of contamination issues and happened more frequently than in previous EQAs [21-23].

In our study, the total number of panels tested by each RT-PCR test did not allow statistically significant conclusions about specific methods that laboratories should be advised to use. Nevertheless, for TOSV and USUV, methods other than virus-specific real-time assays provided false-negative results more frequently than virus-specific real-time PCR tests. Although the same trend was not observed for WNV and TBEV, this could be taken into consideration by laboratories to improve the performance of their diagnostic capacity.

Because TOSV is endemic in countries surrounding the Mediterranean Sea, the majority of reference laboratories in Europe deal only with imported TOSV cases [24-28]. The neglected state of TOSV is reflected in the general absence of commercial tests, except for one which was used by one laboratory for the EQA panel. TOSV detection capacity had a geographical and laboratory coverage comparable to USUV, i.e. 32 laboratories in 19 countries which included all participating countries with known TOSV circulation (Croatia, Cyprus, France, Greece, Italy, Portugal and Spain). Bosnia and Herzegovina and Kosovo*, two other European countries with TOSV activity, did not participate in the EQA. Three TOSV lineages circulate in Europe, two of which were represented in the EQA panel, i.e. lineages $A$ 
RT-PCR methods used for Usutu virus RNA detection, external quality assessment for molecular detection of emerging neurotropic viruses, Europe ( $\mathrm{n}=28$ laboratories)

\begin{tabular}{|c|c|c|c|}
\hline Target & Method & Number of laboratories & False-negative \\
\hline \multicolumn{4}{|l|}{ Usutu virus-specific } \\
\hline USUV NS5 & Nikolay et al., $2014[58]^{a}$ & 11 & 1 \\
\hline USUV NS 5 & Cavrini et al., 2011 [59] $^{\text {a }}$ & 5 & none \\
\hline USUV NS 1 & Jöst et al., $2011[60]^{a}$ & 2 & none \\
\hline USUV NS 5 & Weissenböck et al., 2013 [61] $]^{a}$ & 1 & none \\
\hline USUV 3‘UTR & Del Amo et al., 2013 [62] ${ }^{a}$ & 1 & none \\
\hline USUV unknown & Own design ${ }^{b}$ & 4 & none \\
\hline \multicolumn{4}{|l|}{ Pan-flavivirus } \\
\hline Pan-flavi NS5 & Scaramozzino et al., 2001 [51] & 5 & 3 \\
\hline Pan-flavi NS5 & Sanchez-Seco et al., 2005 [52] & 3 & 3 \\
\hline Pan-flavi NS5 & Patel et al., 2013 [54] & 2 & none \\
\hline Pan-flavi NS5 & Vina-Rodriguez et al., 2017 [56] & 1 & 1 \\
\hline Pan-flavi NS5 & Vazques et al., 2012 [57] & 1 & 1 \\
\hline Pan-flavi unknown & Own design & 2 & none \\
\hline Pan-flavi unknown & Genekam (commercial) & 1 & none \\
\hline
\end{tabular}

USUV: Usutu virus.

a Included in statistical analysis as classified as virus-specific real-time RT-PCR.

${ }^{b}$ Excluded from statistical analysis since cannot be classified as real-time RT-PCR or conventional RT-PCR.

and $B$. The third lineage, lineage $C$, has only recently been discovered in Greece and Croatia and could not be included in the panel because the virus isolate was not available at the time. Of the 32 laboratories that tested for TOSV, four laboratories in four countries missed the TOSV lineage B sample; another laboratory in a fifth country missed the lineage A sample. At RT-PCR test level, lineage $A$ was missed with one test while lineage $B$ was missed six times by five RT-PCR tests of which four were conventional RT-PCR methods, despite the fact that the samples had similar viral loads. Apparently some laboratories used systems that were not sensitive enough for detection of TOSV lineage $B$ strains, although this lineage is geographically most widely spread [4]. TOSV RNA loads provided in this EQA were in line with the virological findings in CSF $[29-31,32,33]$. The recent discovery of lineage $C$ merits attention and the capacity of currently described assays to detect such strains need to be verified; since virological and genetic characterisation of this lineage is ongoing in Greece, inclusion of this lineage will be possible in future EQAs. At the country level, three of the five laboratories that missed a TOSV RNA-positive sample were located in a country endemic for TOSV. Better insight into the capability of TOSV molecular detection in Europe should be obtained with a dedicated EQA, including all three lineages at different viral loads, designed for a comparative evaluation of the RT-PCR methods described in the literature.

The widest geographical (32 countries) and laboratory $(n=48)$ coverage was for WNV testing. The WNV lineage 1 sample was missed by five laboratories in five EU/
EEA countries that had never reported an autochthonous WNV case, while WNV lineage 2 was missed by two laboratories in two EU/EEA countries, one of which is endemic for WNV lineage 2. This was the third EQA of molecular detection of WNV within EVD-LabNet and its predecessor ENIVD $[22,23]$. The long history of WNV capability assessments and surveillance in Europe is likely to explain the good scores observed with WNV.

In this panel, USUV was the most recent emerging virus with still accumulating evidence of its relevance for public health and an increasing geographical distribution [13]. This might explain why the testing capability for USUV had the smallest geographical coverage $(n=18$ countries) and number of laboratories $(n=28$ laboratories). This was the first EQA that included USUV and there is no literature on clinically relevant viral loads in plasma. The concentration in this panel $\left(1.6 \times 10^{4}\right.$ copies $\left./ \mathrm{mL}\right)$ was in the range of detected viral loads for the closely related WNV in plasma [34-36]. Looking at the currently known geographical distribution of USUV in Europe, all countries with USUV circulation except Switzerland participated with USUV testing. The USUV-positive sample was missed by seven laboratories in four EU/EEA countries. To gain better insight in the robustness of USUV detection in Europe, a dedicated EQA including a concentration range of USUV genome copies in different matrices (whole blood, plasma and urine) is to be planned.

Although the geographical distribution of TBEV in Europe is broader than that of WNV and the total number of tick-borne encephalitis cases is higher, the number 


\section{FIGURE 4}

Number of laboratories per country that provided results for tick-borne encephalitis virus, external quality assessment for molecular detection of emerging neurotropic viruses, Europe $(\mathrm{n}=42$ laboratories)

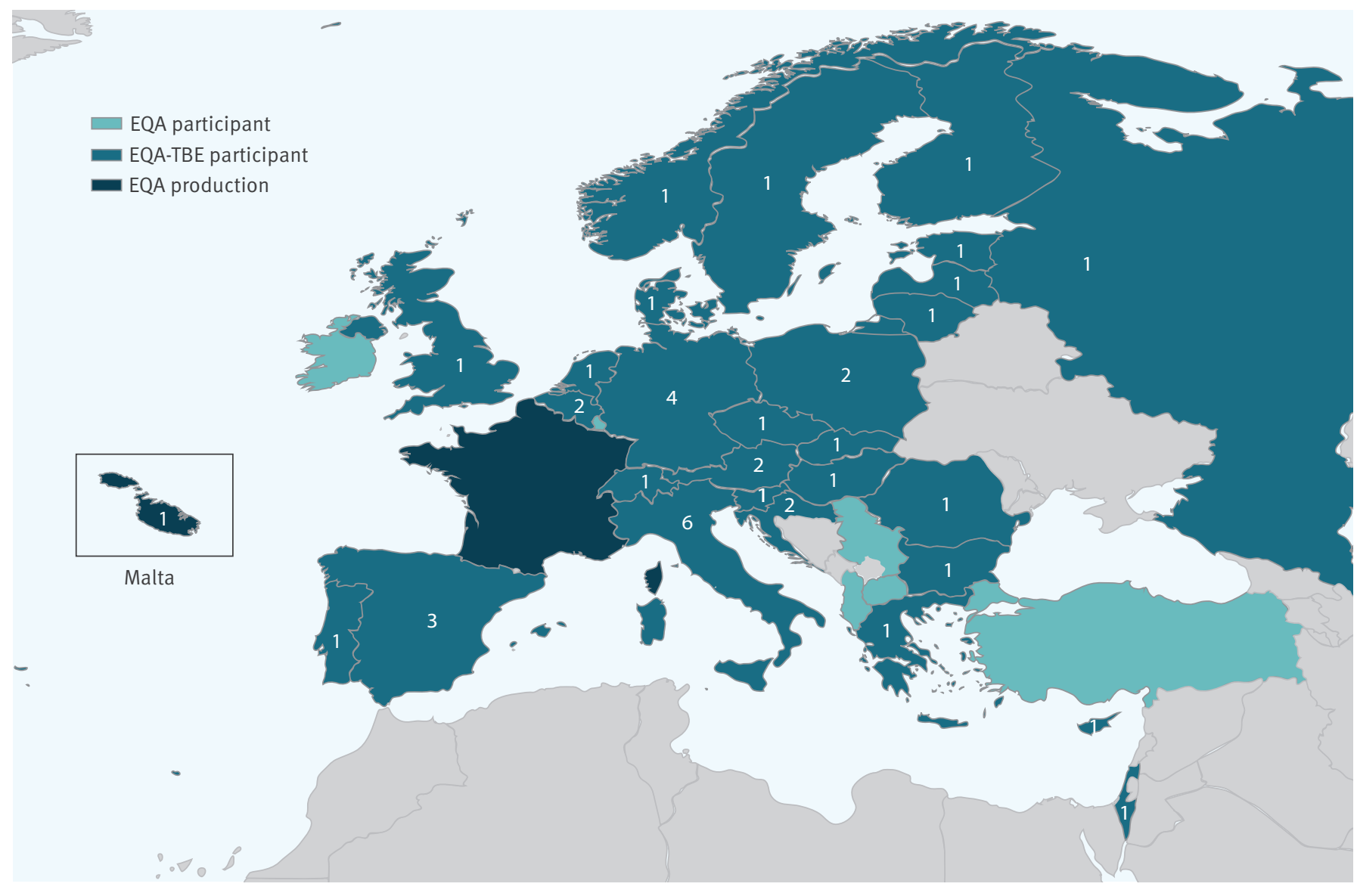

EQA: external quality assessment; TBEV: tick-borne encephalitis virus.

Blue: countries participating with TBEV RNA testing; dark blue: France (the Unite des Virus Emergents (National Reference Centre for arboviruses) at Aix Marseille University prepared and anonymised the panel); light blue: countries that submitted results for viruses other than TBEV.

of laboratories participating with TBEV testing $(n=42)$ and their country coverage $(n=28)$ was smaller than for WNV. The TBEV sample was missed by four laboratories in three countries, of which two display endemic presence of TBEV. This was the second EQA including molecular detection of TBEV within EVD-LabNet and its predecessor ENIVD [21]. However, overall results could not be compared as our EQA only assessed TBEV testing based on one single RNA viral load.

Based on our results, we cannot give advice on what methods to use for the molecular detection of the four viruses. This requires assessment of the whole routine procedure from sample receipt to generation of a result. The performance in the EQA is a combination of the extraction method and the RT-PCR method used, as would routinely be the case when processing reallife diagnostic samples. The set-up of the current EQA cannot assess the influence of the extraction method or RT-PCR system on the final outcome per sample. The background data provided by the participants indicated an important diversity of the methods used for nucleic acid extraction (19 methods). It was impossible to link the extraction method to the quality of the results. To assess solely the quality of the RT-PCR, EQA panels consisting of extracted or synthetic RNA should be provided. Although our study was not designed to address the efficacy of the extraction technique per se, there are many arguments that favour automated extraction protocols over manual protocols. Automated extraction reduces the risk of cross-contamination, the turnaround and hands-on times, provide equivalent amounts of viral RNA and guarantee a better reproducibility compared with manual extraction [37-42]. EQA is an efficient tool to evaluate diagnostic procedures and to alert highlight where improvements are needed. Therefore, we recommend repeating the EQA for laboratories with unsatisfactory results, focusing at least on TOSV and USUV and investigating whether the required improvements are achieved. For these two viruses, we recommend real-time assays rather than classic or nested PCR protocols. 
TABLE 6

RT-PCR methods used for tick-borne encephalitis virus RNA detection, external quality assessment for molecular detection of emerging neurotropic viruses, Europe $(\mathrm{n}=42$ laboratories)

\begin{tabular}{|c|c|c|c|}
\hline Target & Method & Number of laboratories & False-negative \\
\hline \multicolumn{4}{|c|}{ Tick-borne encephalitis virus } \\
\hline TBEV-3'-UTR & Schwaiger et al., 2003 [63] ${ }^{\mathrm{a}}$ & 17 & None \\
\hline TBEV-NS1 & Achazi et al., $2011[64]^{\text {a }}$ & 5 & None \\
\hline $\mathrm{TBEV}^{-\mathrm{NS}_{5}}$ & Puchhammer-Stöckl et al., 1995 [65] & 2 & None \\
\hline TBEV-NS4 & Bago et al., $2002[66]^{b}$ & 1 & None \\
\hline TBEV-5'-UTR & Schrader et al., 1999 [67] & 1 & None \\
\hline TBEV-E & Briggs et al., 2011 [68] & 1 & None \\
\hline TBEV-E & Gäumann et al., $2010[69]^{a}$ & 1 & None \\
\hline TBEV-5'-UTR & Klaus et al., $2010[70]^{a}$ & 1 & None \\
\hline TBEV-3'-UTR & Brinkley et al., $2008[71]^{\mathrm{b}}$ & 1 & None \\
\hline TBEV-E & Andreassen et al., 2012 [72] ${ }^{\mathrm{a}}$ & 1 & None \\
\hline TBEV-E & Skarpaas et al., 2006 [73] & 1 & None \\
\hline TBEV-various & Own design ${ }^{b}$ & 2 & None \\
\hline TBEV Unknown & Genesig (commercial)a & 1 & 1 \\
\hline TBEV Unknown & Amplisense (commercial) ${ }^{\mathrm{a}}$ & 2 & 1 \\
\hline TBEV Unknown & Viasure $\left(\right.$ commercial) ${ }^{\mathrm{a}}$ & 1 & None \\
\hline \multicolumn{4}{|l|}{ Pan-flavivirus } \\
\hline Pan-flavi NS5 & Scaramozzino et al., 2001 [51] & 7 & None \\
\hline Pan-flavi NS5 & Sanchez-Seco et al., 2005 [52] & 3 & 2 \\
\hline Pan-flavi NS 5 & Moureau et al., 2007 [53] & 1 & None \\
\hline Pan-flavi NS 5 & Patel et al., 2013 [54] & 2 & None \\
\hline Pan-flavi NS5 & Briese et al., 1999 [55] & 1 & None \\
\hline Pan-flavi NS 5 & Vina-Rodriguez et al., 2017 [56] & 1 & None \\
\hline Pan-flavi NS 5 & Vazques et al., 2012 [57] & 1 & None \\
\hline Pan-flavi unknown & Own design & 2 & None \\
\hline Pan-flavi unknown & Genekam (commercial) & 1 & None \\
\hline Pan-flavi unknown & TibMolBiol (commercial) & 1 & None \\
\hline
\end{tabular}

TBEV: tick-borne encephalitis virus.

${ }^{\text {a }}$ Included in statistical analysis as classified as virus-specific real-time RT-PCR.

${ }^{b}$ Excluded from statistical analysis since cannot be classified as real-time RT-PCR or conventional RT-PCR.

\section{Conclusion}

Early detection of neurotropic arboviruses allows for timely risk assessment and risk management measures. We observed wide variation in both extraction methods and RT-PCR tests, showing a profound absence of standardisation across European laboratories. Overall, the results were not satisfactory and indicated a need for improvement of capacity and capability. Testing for WNV and TBEV, for which EQAs had been organised previously, showed better results than testing for USUV and TOSV for which this EQA was the first. This trend is important to consider and suggests that EQA exercises for TOSV and USUV should be repeated in order to assess whether successful improvements have been made.
${ }^{\star}$ Note

This designation is without prejudice to positions on status, and is in line with UNSCR 1244 and the ICJ Opinion on the Kosovo Declaration of Independence

\section{Acknowledgements}

We thank all EQA participants: Institute of Virology, University of Veterinary Medicine Vienna, Vienna, Austria; Center for Virology, Medical University of Vienna, Vienna, Austria; Institute of Tropical Medicine; Central Laboratory for Clinical Biology, Antwerp, Belgium; Viral diseases, Scientific Public Health Institute, Brussels, Belgium; Microbiology department, National Center of Infectious and Parasitic Diseases, Sofia, Bulgaria; Research unit, University Hospital for Infectious Diseases "Dr. Fran Mihaljevic", Zagreb; Microbiology, CNPHI, Zagreb, Croatia; Department of Molecular Virology, Cyprus Institute of Neurology and Genetics, Nicosia, Cyprus; Dept. of molecular biology, Institute of Public Health, Ostrava, the Czech Republic; Virus and Microbiological Special Diagnostics, Statens Serum Institut, Copenhagen, Denmark; Virology Department, National Institute for Health Development, Tallinn, Lithuania; 
University of Helsinki and Helsinki University Hospital, Department of Virology and Immunology, Helsinki, Finland; Centre for Biological Threats and Special Pathogens, ZBS1 Highly Pathogenic Viruses, Robert Koch Institute, Berlin, Germany; Charité - Universitätsmedizin Berlin, Institute of Virology, Berlin, Germany; Bundeswehr Institute of Microbiology; Central Diagnostic Unit, Munich, Germany; Institute of Novel and Emerging Infectious Diseases, Friedrich-Loeffler-Institut, Greifswald-Insel Riems, Germany; Public health Laboratories, Hellenic Pasteur Institute, Athens, Greece; National Public Health Institute, Budapest, Hungary; National Virus Reference Laboratory, University College Dublin, Belfield, Dublin, Ireland; Az. OspedalieroUniversitaria di Bologna, Policlinico S. Orsola-Malpighi, Bologna, Italy; Microbiology and Virology Unit, Padova University Hospital, Padova, Italy; Department of Infectious Diseases, Istituto Superiore di Sanità, Rome, Italy; Infectious Diseases, Amedeo di Savoia Hospital, Torino, Italy; Microbiology and Virology Department, Fondazione IRCCS Policlinico San Matteo, Pavia, Italy; Laboratory of Virology, National Institute for Infectious Diseases Lazzaro Spallanzani IRCCS, Rome, Italy; Riga East University hospital Latvian Centre of Infectious Diseases, Riga, Latvia; Clinical testing department, National public health surveillance laboratory, Vilnius, Estonia; Virology-Serology, LNS, Dudelange, Luxembourg, Luxembourg; Molecular Diagnostics Mater Dei Hospital, Msida, Malta; Department of Virology, Norwegian Institute of Public Health, Oslo, Norway; Department of Virology, National Institute of Public Health-National Institute of Hygiene, Warsaw, Poland; Virology Laboratory, BTTIC MIHE, Pulawy, Poland; Center for Vectors and Infectious Diseases Research, National Institut of Health. Águas de Moura, Portugal; Laboratory for vector-borne diseases, National Institute of Research Cantacuzino, Bucharest, Romania; Institute of Virology, Biomedical Research Center, Bratislava, Slowaka; Institute of Microbiology and Immunology, Faculty of Medicine, University of Ljubljana, Ljubljana, Slovenia; Exotic disease, CReSA-IRTA, Barcelona, Spain; Servicio de Microbiología; Hospital Virgen de las Nieves, Granada, Spain; Laboratory of Arboviruses and Viral imported Diseases. National Center of Microbiology. Institute of Health "Carlos III", Madrid, Spain; Hospital Clinic de Barcelona, Barcelona, Spain; Public Health Agency Sweden, Microbiology, Stockholm Sweden; RIPL, NIS Public Health England Porton Down, UK. Control of Infectious Diseases Department, Institute of Public Health, Tirana, Albania; Laboratory for virology and molecular diagnostics, Institute of Public Health of the Republic of North Macedonia, Skopje, North Macedonia; Department for Laboratory Diagnostic, NRL for ARBO viruses and haemorrhagic fever, Institute of Virology, Vaccines and Sera "Torlak", Belgrade, Serbia ; Public Health Institution of Turkey, Ankara, Turkey. National Center for Zoonotic Viruses, Central Virology Laboratory Public Health Services, Israel Ministry of Health Chaim Sheba Medical Center Tel - Hashomer, Israel; Federal Budget Institution of Science "Central Research Institute of Epidemiology”, Moscow, Russia; Federal Office for Civil Protection, Spiez Laboratory, Spiez, Switzerland.

Funding: This work was supported by the European Centre for Disease Prevention and Control (ECDC) under specific contract no.3-ECD.8456 for implementation of the framework contract $E C D C / 2016 / 002$. Several virus strains were provided by the European Virus Archive goes Global (EVAg) project that has received funding from the European Union's Horizon 2020 research and innovation program under grant agreement No 653316.

\section{Conflict of interest}

None declared.
Authors' contributions

Chantal Reusken: design, organisation, analysis, pretested the panel, MS corrections. Cecile Baronti: preparation of the material of EQA. Ramona Mögling: logistics, analysis of the results, MS corrections. Anna Papa: design, pretested the panel, MS corrections. Katrin Leitmeyer: design, analysis of the results, MS corrections. Remi N. Charrel: design, organisation, supervised material preparation, results analysis, MS writing.

\section{References}

1. Glaser C, Bloch K. Encephalitis: why we need to keep pushing the envelope. Clin Infect Dis. 2009;49(12):1848-50. https:// doi.org/10.1086/648420 PMID: 19929385

2. Papa A, Kotrotsiou T, Papadopoulou E, Reusken C, GeurtsvanKessel C, Koopmans M. Challenges in laboratory diagnosis of acute viral central nervous system infections in the era of emerging infectious diseases: the syndromic approach. Expert Rev Anti Infect Ther. 2016;14(9):829-36. https://doi.org/10.1080/14787210.2016.1215914 PMID: 27458693

3. Reusken CBEM, leven M, Sigfrid L, Eckerle I, Koopmans M. Laboratory preparedness and response with a focus on arboviruses in Europe. Clin Microbiol Infect. 2018;24(3):221-8. https://doi.org/10.1016/j.cmi.2017.12.010 PMID: 29274465

4. Alkan C, Bichaud L, de Lamballerie X, Alten B, Gould EA, Charrel RN. Sandfly-borne phleboviruses of Eurasia and Africa: epidemiology, genetic diversity, geographic range, control measures. Antiviral Res. 2013;100(1):54-74. https://doi. org/10.1016/j.antiviral.2013.07.005 PMID: 23872312

5. Marchi S, Trombetta CM, Kistner O, Montomoli E. Seroprevalence study of Toscana virus and viruses belonging to the Sandfly fever Naples antigenic complex in central and southern Italy. J Infect Public Health. 2017;10(6):866-9. https://doi.org/10.1016/j.jiph.2017.02.001 PMID: 28237695

6. Alkan C, Allal-Ikhlef AB, Alwassouf S, Baklouti A, Piorkowski $\mathrm{G}$, de Lamballerie $\mathrm{X}$, et al. Virus isolation, genetic characterization and seroprevalence of Toscana virus in Algeria. Clin Microbiol Infect. 2015;21(11):1040.e1-9. https:// doi.org/10.1016/j.cmi.2015.07.012 PMID: 26235198

7. Sakhria S, Bichaud L, Mensi M, Salez N, Dachraoui K, Thirion $\mathrm{L}$, et al. Co-circulation of Toscana virus and Punique virus in northern Tunisia: a microneutralisation-based seroprevalence study. PLoS Negl Trop Dis. 2013;7(9):e2429. https://doi. org/10.1371/journal.pntd.0002429 PMID: 24069484

8. Charrel RN, Gallian P, Navarro-Mari JM, Nicoletti L, Papa A, Sánchez-Seco MP, et al. Emergence of Toscana virus in Europe. Emerg Infect Dis. 2005;11(11):1657-63. https://doi.org/10.3201/ eid1111.050869 PMID: 16318715

9. Gossner CM, Marrama L, Carson M, Allerberger F, Calistri $P$, Dilaveris D, et al. West Nile virus surveillance in Europe: moving towards an integrated animal-human-vector approach. Euro Surveill. 2017;22(18):30526. https://doi. org/10.2807/1560-7917.ES.2017.22.18.30526 PMID: 28494844

10. Barrett ADT. West Nile in Europe: an increasing public health problem. J Travel Med. 2018;25(1). https://doi.org/10.1093/ jtm/tayo96 PMID: 30289526

11. Eybpoosh S, Fazlalipour M, Baniasadi V, Pouriayevali MH, Sadeghi F, Ahmadi Vasmehjani A, et al. Epidemiology of West Nile Virus in the Eastern Mediterranean region: A systematic review. PLoS Negl Trop Dis. 2019;13(1):e0007081. https://doi. org/10.1371/journal.pntd.0007081 PMID: 30695031

12. Sambri V, Capobianchi MR, Cavrini F, Charrel R, DonosoMantke O, Escadafal C, et al. Diagnosis of West Nile virus human infections: overview and proposal of diagnostic protocols considering the results of external quality assessment studies. Viruses. 2013;5(10):2329-48. https://doi. org/10.3390/v5102329 PMID: 24072061

13. Zannoli S, Sambri V. West Nile virus and Usutu virus cocirculation in Europe: epidemiology and implications. Microorganisms. 2019;7(7):E184. https://doi.org/10.3390/ microorganisms7070184 PMID: 31248051

14. European Centre for Disease Prevention and Control (ECDC). Epidemiological situation of tick-borne encephalitis in the European Union and European Free Trade Association countries. Stockholm: ECDC; 2012 . Available from: https:// ecdc.europa.eu/sites/portal/files/media/en/publications/ Publications/TBE-in-EU-EFTA.pdf

15. European Centre for Disease Prevention and Control (ECDC). Surveillance report: Annual Epidemiological Report for 2015, West Nile fever. Stockholm: ECDC; 2017. Available from: 
https://ecdc.europa.eu/sites/portal/files/documents/AER for_2015-West-Nile-fever.pdf

16. West Nile virus, lineage 1 strain UVE/WNV/2001/FR/DON2001. Marseille: European Virus Archive. [Accessed: 29 Nov 2019]. Available from: https://www.european-virus-archive.com/ virus/west-nile-virus-strain-uvewnv2001frdon2001

17. Toscana virus lineage A, strain UVE/TOSV/2010/TN/T152. Marseille: European Virus Archive. [Accessed: 29 Nov 2019]. Available from: https://www.european-virus-archive.com/ virus/toscana-virus-strain-uvetosv2010tn-t152

18. Toscana virus lineage B, strain UVE/TOSV/2010/FR/4319: EVAg. Marseille: European Virus Archive. [Accessed: 29 Nov 2019]. Available from: https://www.european-virus-archive.com/ virus/toscana-virus-strain-uvetosv2010fr4319

19. Tick-borne encephalitis virus Western subtype, strain UVE/ TBEV/1953/CZ/Hypr. Marseille: European Virus Archive. [Accessed: 29 Nov 2019]. Available from: https://www. european-virus-archive.com/virus/tick-borne-encephalitisvirus-western-subtype-strain-uvetbev1953czhypr

20. Usutu virus, strain Turdus merula Netherlands 2016. Marseille: European Virus Archive. [Accessed: 29 Nov 2019]. Available from: https://www.european-virus-archive.com/virus/ usuv-turdus-merula-netherlands-2016

21. Donoso Mantke O, Aberle SW, Avsic-Zupanc T, Labuda M, Niedrig M. Quality control assessment for the PCR diagnosis of tick-borne encephalitis virus infections. J Clin Virol. 2007;38(1):73-7. https://doi.org/10.1016/j.jcv.2006.09.001 PMID: 17070730

22. Linke S, Mackay WG, Scott C, Wallace P, Niedrig M. Second external quality assessment of the molecular diagnostic of West Nile virus: are there improvements towards the detection of WNV? J Clin Virol. 2011;52(3):257-60. https://doi. org/10.1016/j.jcv.2011.08.010 PMID: 21893429

23. Niedrig M, Linke S, Zeller H, Drosten C. First international proficiency study on West Nile virus molecular detection. Clin Chem. 2006;52(10):1851-4. https://doi.org/10.1373/ clinchem.2005.064451 PMID: 16887901

24. Epelboin L, Hausfater P, Schuffenecker I, Riou B, Zeller H, Bricaire $\mathrm{F}$, et al. Meningoencephalitis due to Toscana virus in a French traveler returning from central Italy. J Travel Med. 2008;15(5):361-3. https://doi.org/10.1111/j.17088305.2008.00221.x PMID: 19006512

25. Kay MK, Gibney KB, Riedo FX, Kosoy OL, Lanciotti RS, Lambert AJ. Toscana virus infection in American traveler returning from Sicily, 2009. Emerg Infect Dis. 2010;16(9):1498-500. https:// doi.org/10.3201/eid1609.100505 PMID: 20735948

26. Howell BA, Azar MM, Landry ML, Shaw AC. Toscana virus encephalitis in a traveler returning to the United States. I Clin Microbiol. 2015;53(4):1445-7. https://doi.org/10.1128/ JCM.03498-14 PMID: 25673791

27. Arden KE, Heney C, Shaban B, Nimmo GR, Nissen MD, Sloots TP, et al. Detection of Toscana virus from an adult traveler returning to Australia with encephalitis. J Med Virol. 2017;89(10):1861-4. https://doi.org/10.1002/jmv.24839 PMID: 28464308

28. Dominati A, Sap L, Vora S. [Fever in a returning traveler from Tuscany]. Rev Med Suisse. 2018;14(592):294-6. PMID: 29384278

29. Pérez-Ruiz M, Collao X, Navarro-Marí JM, Tenorio A. Reverse transcription, real-time PCR assay for detection of Toscana virus. J Clin Virol. 2007;39(4):276-81. https://doi. org/10.1016/j.jcv.2007.05.003 PMID: 17584525

30. Weidmann M, Sanchez-Seco MP, Sall AA, Ly PO, Thiongane Y, Lô MM, et al. Rapid detection of important human pathogenic Phleboviruses. J Clin Virol. 2008;41(2):138-42. https://doi. org/10.1016/j.jcv.2007.10.001 PMID: 18006376

31. Brisbarre N, Plumet S, Cotteaux-Lautard C, Emonet SF, Pages F, Leparc-Goffart I. A rapid and specific real time RT-PCR assay for diagnosis of Toscana virus infection. J Clin Virol. 2015;66:107-11. https://doi.org/10.1016/j.jcv.2015.03.007 PMID: 25866349

32. Marlinge M, Crespy L, Zandotti C, Piorkowski G, Kaphan E, Charrel RN, et al. A febrile meningoencephalitis with transient central facial paralysis due to Toscana virus infection, southeastern France, 2014. Euro Surveill. 2014;19(48):20974. https://doi.org/10.2807/1560-7917.ES2014.19.48.20974 PMID: 25496570

33. Nougairede A, Bichaud L, Thiberville SD, Ninove L, Zandotti $C$, de Lamballerie $X$, et al. Isolation of Toscana virus from the cerebrospinal fluid of a man with meningitis in Marseille, France, 2010. Vector Borne Zoonotic Dis. 2013;13(9):685-8. https://doi.org/10.1089/vbz.2013.1316 PMID: 23808972

34. Pfleiderer C, Blümel J, Schmidt M, Roth WK, Houfar MK, Eckert J, et al. West Nile virus and blood product safety in Germany.
J Med Virol. 2008;80(3):557-63. https://doi.org/10.1002/ jmv.21110 PMID: 18205233

35. Lai L, Lee TH, Tobler L, Wen L, Shi P, Alexander J, et al. Relative distribution of West Nile virus RNA in blood compartments: implications for blood donor nucleic acid amplification technology screening. Transfusion. 2012;52(2):447-54. https:// doi.org/10.1111/j.1537-2995.2011.03289.x PMID: 21827506

36. Lanteri MC, Lee TH, Wen L, Kaidarova Z, Bravo MD, Kiely NE, et al. West Nile virus nucleic acid persistence in whole blood months after clearance in plasma: implication for transfusion and transplantation safety. Transfusion. 2014;54(12):3232-41. https://doi.org/10.1111/trf.12764 PMID: 24965017

37. Fischer C, Pedroso C, Mendrone A Jr, Bispo de Filippis AM, Vallinoto ACR, Ribeiro BM, et al. External Quality Assessment for Zika Virus Molecular Diagnostic Testing, Brazil. Emerg Infect Dis. 2018;24(5):888-92. https://doi.org/10.3201/ eid2405.171747 PMID: 29470164

38. Dundas N, Leos NK, Mitui M, Revell P, Rogers BB. Comparison of automated nucleic acid extraction methods with manual extraction. J Mol Diagn. 2008;10(4):311-6. https://doi. org/10.2353/jmoldx.2008.070149 PMID: 18556770

39. Knepp JH, Geahr MA, Forman MS, Valsamakis A. Comparison of automated and manual nucleic acid extraction methods for detection of enterovirus RNA. J Clin Microbiol. 2003;41(8):35326. https://doi.org/10.1128/JCM.41.8.3532-3536.2003 PMID: 12904351

40. Witlox KJ, Nguyen TN, Bruggink LD, Catton MG, Marshall JA. A comparative evaluation of the sensitivity of two automated and two manual nucleic acid extraction methods for the detection of norovirus by RT-PCR. J Virol Methods. 2008;150(1-2):702. https://doi.org/10.1016/j.jviromet.2008.02.010 PMID: 18400313

41. Wozniak A, Geoffroy E, Miranda C, Castillo C, Sanhueza F, García P. Comparison of manual and automated nucleic acid extraction methods from clinical specimens for microbial diagnosis purposes. Diagn Microbiol Infect Dis. 2016;86(3):268-9. https://doi.org/10.1016/j. diagmicrobio.2016.07.008 PMID: 27543377

42. Yang JL, Wang MS, Cheng AC, Pan KC, Li CF, Deng SX. A simple and rapid method for extracting bacterial DNA from intestinal microflora for ERIC-PCR detection. World I Gastroenterol. 2008;14(18):2872-6. https://doi.org/10.3748/wjg.14.2872 PMID: 18473413

43. Sánchez-Seco MP, Echevarría IM, Hernández L, Estévez D, Navarro-Marí JM, Tenorio A. Detection and identification of Toscana and other phleboviruses by RT-nested-PCR assays with degenerated primers. J Med Virol. 2003;71(1):140-9. https://doi.org/10.1002/jmv.10465 PMID: 12858420

44. Lambert AJ, Lanciotti RS. Consensus amplification and novel multiplex sequencing method for S segment species identification of 47 viruses of the Orthobunyavirus, Phlebovirus, and Nairovirus genera of the family Bunyaviridae. J Clin Microbiol. 2009;47(8):2398-404. https://doi. org/10.1128/JCM.00182-09 PMID: 19535518

45. Linke S, Ellerbrok H, Niedrig M, Nitsche A, Pauli G. Detection of West Nile virus lineages 1 and 2 by real-time PCR. J Virol Methods. 2007;146(1-2):355-8. https://doi.org/10.1016/j. jviromet.2007.05.021 PMID: 17604132

46. Eiden M, Vina-Rodriguez A, Hoffmann B, Ziegler U, Groschup $\mathrm{MH}$. Two new real-time quantitative reverse transcription polymerase chain reaction assays with unique target sites for the specific and sensitive detection of lineages 1 and 2 West Nile virus strains. J Vet Diagn Invest. 2010;22(5):748-53. https://doi.org/10.1177/104063871002200515 PMID: 20807934

47. Tang Y, Anne Hapip C, Liu B, Fang CT. Highly sensitive TaqMan RT-PCR assay for detection and quantification of both lineages of West Nile virus RNA. J Clin Virol. 2006;36(3):177-82. https:// doi.org/10.1016/j.jcv.2006.02.008 PMID: 16675298

48. Lanciotti RS, Kerst AJ, Nasci RS, Godsey MS, Mitchell CJ, Savage HM, et al. Rapid detection of west nile virus from human clinical specimens, field-collected mosquitoes, and avian samples by a TaqMan reverse transcriptase-PCR assay. Clin Microbiol. 2000;38(11):4066-71. PMID: 11060069

49. Shi P, Kauffman E, Ren P, Felton A, Tai J, Dupuis A, et al. Highthroughput detection of West Nile virus RNA. J Clin Microbiol. 2001;39(4):1264-71.

50. Chaskopoulou A, Dovas C, Chaintoutis S, Bouzalas I, Ara G, Papanastassopoulou M. Evidence of enzootic circulation of West Nile virus (Nea Santa-Greece-2010, lineage 2), Greece, May to July 2011. Euro Surveill. 2011;16(31):19933. PMID: 21871217

51. Scaramozzino N, Crance JM, Jouan A, DeBriel DA, Stoll F, Garin D. Comparison of flavivirus universal primer pairs and development of a rapid, highly sensitive heminested reverse transcription-PCR assay for detection of flaviviruses targeted to a conserved region of the NS 5 gene sequences. J 
Clin Microbiol. 2001;39(5):1922-7. https://doi.org/10.1128/ JCM.39.5.1922-1927.2001 PMID: 11326014

52. Sánchez-Seco MP, Rosario D, Domingo C, Hernández L, Valdés K, Guzmán MG, et al. Generic RT-nested-PCR for detection of flaviviruses using degenerated primers and internal control followed by sequencing for specific identification. J Virol Methods. 2005;126(1-2):101-9. https://doi.org/10.1016/j. jviromet.2005.01.025 PMID: 15847925

53. Moureau G, Temmam S, Gonzalez JP, Charrel RN, Grard G, de Lamballerie X. A real-time RT-PCR method for the universal detection and identification of flaviviruses. Vector Borne Zoonotic Dis. 2007;7(4):467-77. https://doi.org/10.1089/ vbz.2007.0206 PMID: 18020965

54. Patel P, Landt O, Kaiser M, Faye O, Koppe T, Lass U, et al. Development of one-step quantitative reverse transcription PCR for the rapid detection of flaviviruses. Virol J. 2013;10(1):58. https://doi.org/10.1186/1743-422X-10-58 PMID: 23410000

55. Briese T, Jia XY, Huang C, Grady LJ, Lipkin WI. Identification of a Kunjin/West Nile-like flavivirus in brains of patients with New York encephalitis. Lancet. 1999;354(9186):1261-2. https://doi. org/10.1016/S0140-6736(99)04576-6 PMID: 10520637

56. Vina-Rodriguez A, Sachse K, Ziegler U, Chaintoutis SC, Keller M, Groschup MH, et al. A Novel Pan-Flavivirus Detection and Identification Assay Based on RT-qPCR and Microarray. BioMed Res Int. 2017;2017:4248756. https://doi. org/10.1155/2017/4248756 PMID: 28626758

57. Vázquez A, Sánchez-Seco MP, Palacios G, Molero F, Reyes $\mathrm{N}$, Ruiz $\mathrm{S}$, et al. Novel flaviviruses detected in different species of mosquitoes in Spain. Vector Borne Zoonotic Dis. 2012;12(3):223-9. https://doi.org/10.1089/vbz.2011.0687 PMID: 22022811

58. Nikolay B, Weidmann M, Dupressoir A, Faye O, Boye CS, Diallo $M$, et al. Development of a Usutu virus specific realtime reverse transcription PCR assay based on sequenced strains from Africa and Europe. J Virol Methods. 2014;197:514. https://doi.org/10.1016/j.jviromet.2013.08.039 PMID: 24036076

59. Cavrini F, Della Pepa ME, Gaibani P, Pierro AM, Rossini G, Landini MP, et al. A rapid and specific real-time RT-PCR assay to identify Usutu virus in human plasma, serum, and cerebrospinal fluid. J Clin Virol. 2011;50(3):221-3. https://doi. org/10.1016/j.jcv.2010.11.008 PMID: 21156352

6o. Jöst H, Bialonski A, Maus D, Sambri V, Eiden M, Groschup MH, et al. Isolation of Usutu virus in Germany. Am J Trop Med Hyg. 2011;85(3):551-3. https://doi.org/10.4269/ajtmh.2011.11-0248 PMID: 21896821

61. Weissenböck H, Bakonyi T, Rossi G, Mani P, Nowotny N. Usutu virus, Italy, 1996. Emerg Infect Dis. 2013;19(2):274-7. https:// doi.org/10.3201/eid1902.121191 PMID: 23347844

62. Del Amo J, Sotelo E, Fernández-Pinero J, Gallardo C, Llorente $\mathrm{F}$, Agüero $M$, et al. A novel quantitative multiplex real-time RT-PCR for the simultaneous detection and differentiation of West Nile virus lineages 1 and 2, and of Usutu virus. Virol Methods. 2013;189(2):321-7. https://doi.org/10.1016/j. jviromet.2013.02.019 PMID: 23499258

63. Schwaiger M, Cassinotti P. Development of a quantitative real-time RT-PCR assay with internal control for the laboratory detection of tick borne encephalitis virus (TBEV) RNA. J Clin Virol. 2003;27(2):136-45. https://doi.org/10.1016/S13866532(02)00168-3 PMID: 12829035

64. Achazi K, Růžek D, Donoso-Mantke O, Schlegel M, Ali HS, Wenk $M$, et al. Rodents as sentinels for the prevalence of tick-borne encephalitis virus. Vector Borne Zoonotic Dis. 2011;11(6):641-7. https://doi.org/10.1089/vbz.2010.0236 PMID: 21548766

65. Puchhammer-Stöckl E, Kunz C, Mandl CW, Heinz FX. Identification of tick-borne encephalitis virus ribonucleic acid in tick suspensions and in clinical specimens by a reverse transcription-nested polymerase chain reaction assay. Clin Diagn Virol. 1995;4(4):321-6. https://doi.org/10.1016/09280197(95)00022-4 PMID: 15566853

66. Bagó Z, Bauder B, Kolodziejek J, Nowotny N, Weissenböck H. Tickborne encephalitis in a mouflon (Ovis ammon musimon). Vet Rec. 2002;150(7):218-20. https://doi.org/10.1136/ vr.150.7.218 PMID: 11878442

67. Schrader C, Süss J. A nested RT-PCR for the detection of tick-borne encephalitis virus (TBEV) in ticks in natural foci. Zentralbl Bakteriol. 1999;289(3):319-28. https://doi. org/10.1016/S0934-8840(99)80069-3 PMID: 10467662

68. Briggs BJ, Atkinson B, Czechowski DM, Larsen PA, Meeks HN, Carrera JP, et al. Tick-borne encephalitis virus, Kyrgyzstan. Emerg Infect Dis. 2011;17(5):876-9. https://doi.org/10.3201/ eid1705.101183 PMID: 21529400

69. Gäumann R, Mühlemann K, Strasser M, Beuret C. Highthroughput procedure for tick surveys of tick-borne encephalitis virus and its application in a national surveillance study in Switzerland. Appl Environ Microbiol. 2010;76(13):4241-9.

70. Klaus C, Hoffmann B, Hering U, Mielke B, Sachse K, Beer $M$, et al. Tick-borne encephalitis (TBE) virus prevalence and virus genome characterization in field-collected ticks (Ixodes ricinus) from risk, non-risk and former risk areas of TBE, and in ticks removed from humans in Germany. Clin Microbiol Infect. 2010;16(3):238-44. https://doi.org/10.1111/j.14690691.2009.02764.x PMID: 19906276

71. Brinkley C, Nolskog P, Golovljova I, Lundkvist Å, Bergström T. (Tick-borne encephalitis virus natural foci emerge in western Sweden. Int J Med Microbiol. 2008;298(Suppl. 1):73-80. https://doi.org/10.1016/j.ijmm.2007.12.005

72. Andreassen A, Jore S, Cuber P, Dudman S, Tengs T, Isaksen K, et al. Prevalence of tick borne encephalitis virus in tick nymphs in relation to climatic factors on the southern coast of Norway. Parasit Vectors. 2012;5(1):177. https://doi.org/10.1186/17563305-5-177 PMID: 22913287

73. Skarpaas T, Golovljova I, Vene S, Ljøstad U, Sjursen H, Plyusnin A, et al. Tickborne encephalitis virus, Norway and Denmark. Emerg Infect Dis. 2006;12(7):1136-8. https://doi. org/10.3201/eid1207.051567 PMID: 16836835

\section{License, supplementary material and copyright}

This is an open-access article distributed under the terms of the Creative Commons Attribution (CC BY 4.0) Licence. You may share and adapt the material, but must give appropriate credit to the source, provide a link to the licence and indicate if changes were made.

Any supplementary material referenced in the article can be found in the online version.

This article is copyright of the authors or their affiliated institutions, 2019. 